April - 2009

Regional Focus Issue: Bridge over Troubled Waters Cengiz Hakan Aydin and Yoram EshetAlkalai, IRRODL Regional Editors for the Middle East

\title{
Quality of Distance Education in Turkey: Preschool Teacher Training Case
}

\author{
Mehmet Gültekin \\ Anadolu University, Turkey
}

\begin{abstract}
Distance education is used for teacher training at different levels and fields in Turkey. Launched in the 2000-01 academic year and still applied by Anadolu University, the Preschool Teacher Training Program is one of those programs offered by distance education. This study aims to evaluate Anadolu University's Preschool Teacher Training Program in Turkey by obtaining student opinions. A total of 1,026 senior students enrolled in the Preschool Education major at the Open Education Faculty of Anadolu University participated in the survey. A questionnaire to determine the opinions of students about the program was used as a means of data collection. Means (X) and standard deviations (SD) were employed to analyze the survey data. The results showed that although the teacher candidates study at a good level, they do not have a good record of watching the television programs. The results also revealed that the opinions of teacher candidates about the textbooks, television programs, teaching practices, and academic assistance services are positive.
\end{abstract}

Keywords: Distance education; teacher training; preschool education; program evaluation

\section{Introduction}

Distance education is a new means of training teachers, but there's a limited amount of research on this practice, and most of it is performed in developed countries (Edwards, 2005). However, it has been stated that the use of distance education in teacher training has yielded positive outcomes (Uşun, 2003; Perraton, Creed, \& Robinson, 2002; Moon, 1997; Evans \& Nation, 1993; Prescott \& Robinson, 1993; Demiray, McIsaac, \& Yangın 1993; Anderson \& Simpson (2005), Nielsen \& Tatto, 1991). There is good evidence that the distance education programmes in the field of knowledge, general culture, educational theories, and practical dimensions of teacher training have been successful (Perreaton, Creed, \& Robinson, 2001). Studies concerning teacher training practices performed in such countries as Tanzania, Guyana, Zimbabwe, Sri Lanka, and Indonesia also indicate that the teachers trained through distance education might be as good as and, in some cases, better than the teachers trained through the traditional method (Yates, 2000). 
In addition, it has been argued that the teachers who participate in teacher training via distance education consider distance education programmes to be equal to face-to-face programmes (Jackson, 2006; Miller, 2000.); teacher training by means of distance education programmes in comparison with traditional programmes is more effective in increasing teachers' knowledge and skills (Shrestha, 1997); and teachers participating in distance education are able to teach more effectively than those participating in traditional programmes (Brophy \& Dudley, 1983; Nielsen $\&$ Tatto, 1991).

Distance education is viewed by those teachers who are willing to improve themselves and manage their time as an accessible and inexpensive approach to teacher training (Martinez, 2002). Therefore, distance education programmes are implemented today in many countries for both preservice and in-service training of teachers (Sherestha, 1997). In their analysis, Perraton, Creed, and Robinson (2001) state that countries adopt the distance education approach for teacher training in order to achieve various aims. These aims are outlined below:

\section{(1) Initial qualification}

Some countries utilize distance education so that a large number of teachers can gain basic qualifications. This practice might occur as a way of enhancing the qualifications of beginner level or low-qualified teachers.

(2) Continuing professional development

Since face-to-face teacher training is not considered efficient in terms of scheduling, distance education is used in order to improve skills, maintain cognitive depth, and expand knowledge. Some programmes might focus on special groups.

(3) Re-orientation for teachers for curriculum reform and change

Distance education plays a significant role in programme reforms aimed at changing educational content and activities. For instance, the programmes intended to contribute to the use of educational technologies at schools are carried out with this aim.

(4) Teachers' career development

Distance education is utilized in order to support teachers' career development. When teachers study for the purpose of professional development, they aim to improve their qualifications so that they can advance to higher level positions, such as head teacher or educational inspector; in short when they need new skills, they derive benefit from distance education.

One of the fundamental problems with the use of distance education in teacher training is how to combine theory with practice (Robinson \& Latchem, 2003). As most of the learning in distance education takes place independently of teachers and is based on the instructional tools prepared beforehand (Evans, 1994), practical activities have strategic significance in teacher training programmes. It is important for teacher candidates to achieve their teacher qualifications, transform theoretical knowledge into practice, and gain positive attitudes regarding the teaching profession.

\section{Anadolu University's Preschool Teacher Education Programme}


In Turkey, distance education is combined with face-to-face education for teacher training. In the 2001-02 academic years, Anadolu University offered undergraduate programmes in order to train preschool and English teachers. Unlike the programmes for primary and secondary education teachers, these two programmes are not intended for employed teachers. They were initiated due to the countrywide need, and they were conducted parallel with face-to-face education. The Open Education Faculty's Programme of Preschool Education, one of the teacher training programmes initiated in the 2001-02 academic year and still continued by Anadolu University, is a unique teacher training programme in terms of its structure and operation.

\section{Programme Content}

The undergraduate programme is designed to equip preschool education students with the knowledge, skills, and attitudes they need. It consists of courses in professional knowledge on teaching, field knowledge, and general culture. The courses in the first year focus on general culture, and those in the last year focus on field knowledge. On the other hand, the courses that focus on professional teaching knowledge are offered throughout the four-year period. The courses offered in the programme are shown in Table 1.

Table 1

OEF Preschool Education Undergraduate Programme Course List

\begin{tabular}{|l|l|l|c|}
\hline 1. Year & \multicolumn{2}{l|}{} \\
\hline Code & Course Name and Branch(es) & Hour $(\boldsymbol{s})$ & ECTS Credit \\
\hline 1337 & Introduction to Education & $3+0$ & 8.0 \\
\hline 1338 & Computer & $3+0$ & 10.0 \\
\hline 1343 & Principles and Methods of Preschool Education & $3+0$ & 10.0 \\
\hline 1344 & Human Anatomy and Physiology & $3+0$ & 8.0 \\
\hline 1345 & Child Developmental Psychology & $3+0$ & 8.0 \\
\hline 1346 & Mother and Child Health and Nutrition & $6+0$ & 10.0 \\
\hline 1216 & German, French, English & $4+0$ & 6.0 \\
\hline 2. Year & & & \\
\hline 2252 & Atatürk's Principles and History of Turkish Revolution & $4+0$ & 6.0 \\
\hline 2352 & Turkish Writing and Speaking Skills & $4+0$ & 6.0 \\
\hline 2353 & Planning and Evaluation in Teaching & $4+0$ & 8.0 \\
\hline 2354 & Development and Learning & $3+0$ & 8.0 \\
\hline 2355 & Teaching Music & $6+0$ & 9.0 \\
\hline 2356 & Language and Concept Development in Children & $3+0$ & 8.0 \\
\hline 2357 & Movement and Game Development in Children & $6+0$ & 9.0 \\
\hline 2358 & Speaking and Writing Education & $6+0$ & 6.0 \\
\hline 3 Year & & & \\
\hline
\end{tabular}




\begin{tabular}{|l|l|l|l||}
\hline 3365 & Classroom Management & $3+0$ & 8.0 \\
\hline 3366 & Counselling & $3+0$ & 10.0 \\
\hline 3368 & Preschool Teaching Drawing & $6+0$ & 6.0 \\
\hline 3369 & Literature for Children & $6+0$ & 5.0 \\
\hline 3370 & Teaching Computers in Preschool Education & $3+0$ & 4.0 \\
\hline 3371 & Parent Education & $3+0$ & 6.0 \\
\hline 3372 & Preschool Science and Mathematics Teaching & $6+0$ & 6.0 \\
\hline 3374 & Practice in Preschool Education & $9+0$ & 6.0 \\
\hline 3377 & Techniques of Individual Recognition & $6+0$ & 5.0 \\
\hline 4. Year & Special Education & $3+0$ & 4.0 \\
\hline 4375 & Development of Individualized Education Programs & $6+0$ & 6.0 \\
\hline 4389 & Special Teaching Methods & $6+0$ & 6.0 \\
\hline 4390 & Creativity In Children and Drama & $6+0$ & 6.0 \\
\hline 4392 & Child Psychology and Adaptation Problems & $3+0$ & 6.0 \\
\hline 4393 & Material Development in Preschool Education & $6+0$ & 6.0 \\
\hline 4394 & Teaching Practice & $5+0$ & 10.0 \\
\hline 4439 & $\begin{array}{l}\text { Training of Children with Hearing, Speaking and Visual } \\
\text { Disabilities. }\end{array}$ & $3+0$ & 6.0 \\
\hline 4440 & $\begin{array}{l}\text { Training of Children with Behavioural and Learning } \\
\text { Problems }\end{array}$ & $3+0$ & 6.0 \\
\hline 4450 & Instructional Technology and Material Development & $3+0$ & 8.0 \\
\hline & & & \\
\hline
\end{tabular}

In addition to the theoretical courses, there are two practical courses in the Programme of Preschool Education: Practice in Preschool Education in the $3^{\text {rd }}$ year and Teaching Practice in the $4^{\text {th }}$ year. Practice in Preschool Education is a course based on the observations, interviews, practices, and evaluations performed in order for teacher candidates to learn about the school where the practicum will take place, the programme, and the teachers. Preschool Education Practice is taken in the third year of the major as one full-day (eight hours) a week for 24 weeks. Teaching Practice is a course aimed at allowing teacher candidates to test and improve the knowledge and skills they acquire through theoretical courses in a school environment and to gain the required professional skills. This course is taken in the fourth year of the programme as one full or two half days a week for 14 weeks.

The practices are carried out as a cooperative venture between the Open Education Faculty and the Ministry of Education. The Open Education Faculty practice coordinator represents the Faculty and the practice school coordinator and practice teacher represent the Ministry of Education, or in other words the practice school. The Directory of Education conducts the necessary administrative tasks within the Open Education Faculty practice school (Gültekin, 2004). Practical manuals designed for teacher candidates are used in conjunction with practice teachers (mentors). The structure of the teaching practices, which are conducted cooperatively 
between Anadolu University and the Ministry of Education, is presented in Figure 1.

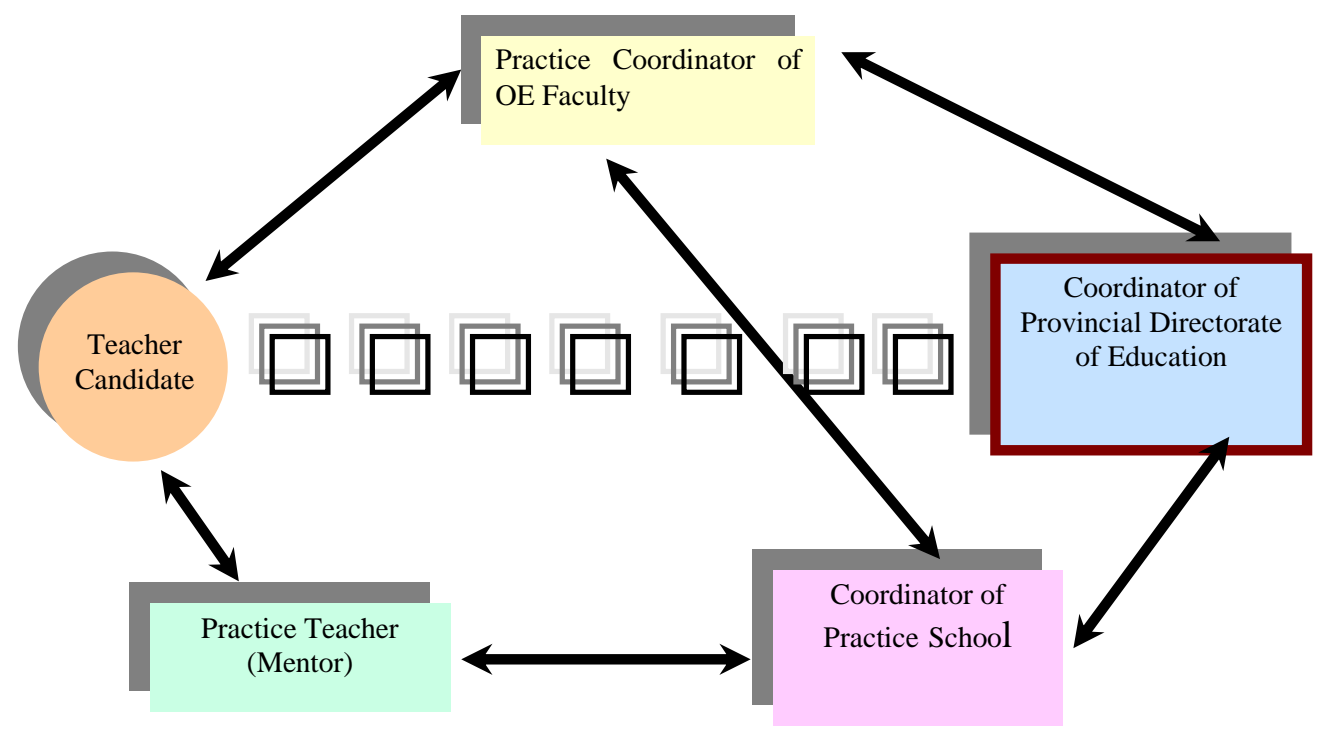

Figure 1. Open Education Faculty Practice School.

Within the scope of this cooperation, teacher candidates perform teaching practices under the guidance of teacher trainers at local nursery schools run by the Ministry of Education. In the 2005-06 academic year, 7,386 senior students - 3,418 in the third year and 4,220 in the fourth year - conducted practices in 213 Ministry of Education nursery schools in 81 provinces; and 81 provincial practice coordinators, 213 practice school coordinators, and 688 practice teachers were appointed to supervise the practices.

\section{Teaching-Learning Processes of the Programme}

The programme consists of printed materials, television programmes, and academic assistance services. Printed materials (books and manuals) are written by field experts under the supervision of an editor. Printed materials are written based on the principles of distance education and in a way that makes self-learning possible. Each unit in the book is made up of aims, table of contents, instructions, the text, summary, questions for evaluation, and the reference list. Twenty-three textbooks were designed for the programme. In addition, 123 television programmes were prepared in order to support the printed materials; there are two to six 20-minute programmes for each course. These television programmes are broadcast on a national television channel twice a day, once in the morning and once in the evening, on scheduled days of the week. In addition to the printed materials and television programmes, some academic assistance services are offered. The academic assistance services are conducted on the Internet and help students with their questions or problems. To supplement the third year Practice in Preschool Education and the fourth year Teaching Practice courses, Internet-supported educational software was developed.

\section{Evaluation of the Programme}


The academic achievement levels of students are assessed through central examinations in accordance with the distance education regulations of Anadolu University. According to the regulations, students take the exams three times a year on the scheduled dates in the academic calendar. Conducted as midterm, final, or make-up exams, they are taken by students in the province where they are registered to a Bureau of Open Education Faculty. The exams are conducted in 81 provincial centres, including Lefkoşa (Northern Cyprus).

All exam questions are prepared in multiple-choice format and assessed on computer. Students are required to pass each test. Scores are marked out of 100. The achievement score of each course is determined by adding $30 \%$ of the midterm score and $70 \%$ of the final or make-up score. In order to prove successful in a course, the achievement score must be 50 out of 100 or higher. If students fail up to a maximum of two courses, they are allowed to take the courses of the following year. Those failing three or more courses repeat the courses failed in the same year and are obliged to retake the exams for these courses. These students cannot advance to the following year's courses (Anadolu University, 2004).

There are no central exams for the practical courses in the programme; rather, students prepare portfolios, and these portfolios are evaluated by the practice teachers in the schools. The portfolios evaluated by the practice teachers are sent to the Evaluation Commission of Practice Portfolio, which is part of the Open Education Faculty, and this commission evaluates the portfolios once more. In the 2005-06 offering of the Preschool Education and Teaching Practice courses, 3,353 third grade and 4,206 fourth grade (total of 7,559) practice portfolios, which were previously evaluated by the practice teacher and sent to Open Education Faculty, were evaluated by the Evaluation Commission of Practice Portfolio (Yaşar, Gültekin, \& Duban, 2006).

The most important issue concerning the teacher training programmes conducted through distance education is the effectiveness of the programme, or, in other words, whether the content is learnt and the desired behaviours are acquired by teachers at the end of the training (Özer, 1993). This survey emerged from the need to determine the opinions of preschool senior students because their opinions will contribute to an assessment of the effectiveness of the preschool education programme.

\section{Aim}

The aim of this research is to evaluate student opinions of Anadolu University's Programme of Preschool Education, which trains preschool teachers through distance education. The answers to the following questions were sought:

1. What is the level at which students study for their lessons and watch the television programmes?

2. What do students think about the following: (a) the textbooks, (b) the television programmes, (c) the teaching practices, (d) the exams, and (e) the academic assistance services? 


\section{Method}

\section{Research Model}

To gather data about student opinions of the Programme of Preschool Education at Anadolu University Open Education Faculty, a survey was designed according to the survey method and conducted through the quantitative research method.

\section{Participants}

The survey was conducted on 1,026 senior students studying Preschool Education at Anadolu University in the 2005-2006 academic years. The research was conducted on senior trainee teachers because they had experienced all aspects of the programme.

As it was not possible to involve all senior students in the research, a sampling was performed among 4,220 senior students conducting their teaching practice in 213 Ministry of Education nursery schools in 81 provinces during the 2005-06 academic years. With this end in mind, five trainee teachers were chosen randomly from each nursery school. Therefore 1,065 senior teacher candidates out of 4,216 were delivered questionnaires. Of these questionnaires, 39 questionnaires were not assessed as they were not properly filled in and, therefore, the research was conducted through the data collected from 1,026 students. The personal characteristics of the students participating in the survey are shown in Table 2.

Table 2

The Personal Characteristics of the Teacher Candidates Participating in the Survey

\begin{tabular}{|l|l|l|}
\hline Characteristic & $\mathbf{f}$ & \% \\
\hline Employment & & \\
\hline Unemployed & 588 & 57.3 \\
\hline Employed & 438 & 42.7 \\
\hline Age & & \\
\hline 22 and younger & 141 & 13.7 \\
\hline $23-27$ & 583 & 56.8 \\
\hline $28-32$ & 194 & 18.9 \\
\hline $33-37$ and older & 95 & 9.3 \\
\hline 38 and older & 13 & 1.3 \\
\hline Total & $\mathbf{1 0 2 6}$ & $\mathbf{1 0 0 . 0}$ \\
\hline
\end{tabular}

As seen in Table 2, 57.3\% of the participant teacher candidates are unemployed and $42.7 \%$ of them are employed; $13.7 \%$ are 22 years old or younger; $56.8 \%$ of them are 23-27 years old; $18.9 \%$ of them are $28-32 ; 9.3 \%$ of them are $33-37$; and $1.3 \%$ of them are 38 years old or older. It 
is clear that more than half the teacher candidates are unemployed and again more than half of them are between 23 and 27 years of age.

\section{Data Collection Tool}

A questionnaire was prepared in order to collect the data within the scope of the research. The questionnaire is made up of two parts. In the first part, there are questions intended to determine the personal characteristics of the participating teacher candidates. In the second part, there are questions intended to determine the opinions of teacher candidates about the textbooks, television programmes, teaching practices, exams, and academic assistance services of the programme studied.

The questionnaire was shown to pre-school education experts. The experts reviewed the questionnaire in terms of content and scope, and they provided their suggestions. Then the questionnaire was redesigned by the researcher according to the experts' suggestions. Afterwards, the questionnaire was taken by 50 students as a pilot study. In order to test the questionnaire's reliability, Cronbach's Alpha was checked and it was found to be .87 .

After the validity and reliability studies were completed, the questionnaires were delivered to the teacher trainees in their nursery schools by mail in May, 2006, and the teacher trainees returned the questionnaires by mail.

\section{Data Analysis}

In order to determine the opinions of teacher candidates concerning the programme studied, the arithmetic means of the points given by trainee teachers to the questionnaire items and standard deviations of the point distributions were calculated. The gained results were interpreted based on the following intervals: 4.21 - 5.00, I strongly agree; $3.41-4.20$, I agree; 2.61 - 3.40, I neither agree nor disagree; 1.81 - 2.60, I disagree; and 1.00 - 1.80, I strongly disagree.

\section{Findings and Interpretation}

The findings gained in the research are presented in the order they are mentioned in the objectives.

\section{The Levels at which Preschool Teacher Candidates Study for their Lessons and Watch the Television Programmes}

The levels at which preschool teacher candidates study for their lessons and watch the television programmes are presented in Table 3.

Table 3 
The Levels at which Preschool Teacher Candidates Study for their Lessons and Watch the Television Programmes

\begin{tabular}{|l|l|l|}
\hline Levels & f & \% \\
\hline Study & & \\
\hline I don't study every day & 442 & 43.1 \\
\hline Less than an hour per day & 73 & 7.1 \\
\hline $1-2$ hours per day & 342 & 33.3 \\
\hline I study 3 hours or more per day & 169 & 16.5 \\
\hline Watch the television programmes & & \\
\hline I watch all of them & 10 & 1.0 \\
\hline I watch most of them & 60 & 5.8 \\
\hline I watch a few of them & 245 & 23.9 \\
\hline I watch very few of them & 224 & 21.8 \\
\hline I never watch & 487 & 47.5 \\
\hline Total & $\mathbf{1 0 2 6}$ & $\mathbf{1 0 0 . 0 0}$ \\
\hline
\end{tabular}

As seen in Table 3, 43.1\% of participant teacher candidates say they don't study every day; $7.1 \%$ of them say they study less than an hour a day; $33.3 \%$ of them say they study one to two hours a day; and $16.5 \%$ of them say they study three or more hours a day. Regarding the television programmes, $1 \%$ of the teacher candidates participating in the survey say they watch all the programmes; $5.8 \%$ of them say they watch most of them; $23.9 \%$ of them say they watch a few of them; and $21.8 \%$ of them saythey watch very few of them, while $47.5 \%$ of the teacher candidates say they never watch. These data indicate that the level at which preschool teacher candidates study for their lessons is good; whereas, the level at which they watch the television programmes is poor.

\section{The Opinions of Preschool Teacher Candidates on the Programme}

\section{Textbooks.}

The opinions of preschool teacher candidates concerning the textbooks are presented in Table 4 .

Table 4

The Opinions of Preschool Teacher Candidates concerning the Textbooks

\begin{tabular}{|l|l|l|l|}
\hline Textbooks & N & - & X \\
\hline Physical Quality & & & \\
\hline The dimensions of textbooks are ergonomic & 1026 & 3.98 & 0.98 \\
\hline The cover cardboard of textbooks is of good quality and & 1026 & 3.88 & 1.01 \\
\hline
\end{tabular}




\begin{tabular}{|c|c|c|c|}
\hline durable & & & \\
\hline The bindings of textbooks are durable & 1026 & 3.87 & 0.99 \\
\hline The covers of textbooks are aesthetically appealing to students & 1026 & 3.46 & 1.12 \\
\hline The paper of textbooks (pattern of the paper) is of good quality & 1026 & 3.26 & 1.20 \\
\hline The publishing quality of the textbooks is sufficient & 1026 & 3.63 & 1.05 \\
\hline \multicolumn{4}{|l|}{ Content } \\
\hline $\begin{array}{l}\text { The knowledge presented in the textbooks is sufficient to } \\
\text { explain the subject }\end{array}$ & 1026 & 3.79 & 0.94 \\
\hline $\begin{array}{l}\text { The knowledge presented in the textbooks is useful for the aim } \\
\text { of the preschool education field, its principles, methods, } \\
\text { operations, and concepts }\end{array}$ & 1026 & 3.96 & 0.88 \\
\hline $\begin{array}{l}\text { When presenting new knowledge in the textbooks, its } \\
\text { relationship to previous knowledge is provided }\end{array}$ & 1026 & 4.20 & 0.68 \\
\hline $\begin{array}{l}\text { The examples provided to support the knowledge in the } \\
\text { textbooks are sufficient }\end{array}$ & 1026 & 4.18 & 0.72 \\
\hline $\begin{array}{l}\text { The knowledge presented in the textbooks is valid and up-to- } \\
\text { date }\end{array}$ & 1026 & 3.93 & 0.94 \\
\hline $\begin{array}{l}\text { The knowledge presented in the textbooks encourages students } \\
\text { to do research, take examinations, make observations and to } \\
\text { think critically and the like }\end{array}$ & 1026 & 4.14 & 0.72 \\
\hline $\begin{array}{l}\text { The knowledge presented in the textbooks is sequenced from } \\
\text { the concrete to the abstract, from the simple to the complex, } \\
\text { and from the known to the unknown }\end{array}$ & 1026 & 3.90 & 0.90 \\
\hline $\begin{array}{l}\text { The objectives, suggestions for further study, summary, and } \\
\text { assessment questions facilitate comprehension of the unit }\end{array}$ & 1026 & 4.08 & 0.78 \\
\hline \multicolumn{4}{|l|}{ Language and Narrative Features } \\
\hline $\begin{array}{l}\text { The punctuation marks are used correctly when presenting the } \\
\text { subjects in the textbooks }\end{array}$ & 1026 & 4.06 & 0.87 \\
\hline The lengths of words are convenient for reading skills & 1026 & 4.16 & 0.68 \\
\hline Foreign words are avoided as much as possible & 1026 & 3.95 & 0.92 \\
\hline $\begin{array}{l}\text { Sentences are written in a short, clear, and grammatically } \\
\text { correct way }\end{array}$ & 1026 & 4.07 & 0.84 \\
\hline $\begin{array}{l}\text { The connections among the paragraphs in a text are well- } \\
\text { established }\end{array}$ & 1026 & 3.91 & 0.95 \\
\hline $\begin{array}{l}\text { Paragraphs are written in a fluent, clear, and comprehensible } \\
\text { way. }\end{array}$ & 1026 & 4.10 & 0.75 \\
\hline \multicolumn{4}{|l|}{ Visual Arrangement } \\
\hline The font of letters in the textbooks is convenient for reading & 1026 & 4.00 & 0.86 \\
\hline $\begin{array}{l}\text { The font of letters is compatible with the content and other } \\
\text { components }\end{array}$ & 1026 & 4.27 & 0.69 \\
\hline The space between lines is convenient for reading & 1026 & 4.26 & 0.65 \\
\hline The arrangement of the titles facilitates comprehension & 1026 & 4.23 & 0.69 \\
\hline Page set up facilitates reading and comprehension & 1026 & 4.17 & 0.73 \\
\hline
\end{tabular}




\begin{tabular}{|l|l|l|l|l|}
\hline $\begin{array}{l}\text { Pictures, photographs, figures, schemas and graphics are } \\
\text { explanatory and facilitate learning }\end{array}$ & 1026 & 3.97 & 0.94 \\
\hline General & $\mathbf{1 0 2 6}$ & $\mathbf{3 . 9 9}$ & $\mathbf{0 . 5 7}$ \\
\hline
\end{tabular}

Preschool teacher candidates state that they strongly agree with the following items concerning the physical quality of the textbooks: the dimensions of textbooks are ergonomic $(X=3.98)$, the cover cardboard of textbooks is of good quality and durable $(\mathrm{X}=3.88)$, the bindings of textbooks are durable $(X=3.87)$, the publishing quality of the textbooks is sufficient $(X=3.63)$, and the covers of textbooks are aesthetically appealing to students $(X=3.46)$. On the other hand, they state that they neither agree nor disagree with the item that the paper of textbooks (pattern of the paper) is of good quality $(X=3.26)$. Considered from a general perspective, it is evident that teacher candidates find the physical quality of the textbooks appropriate.

Preschool teacher candidates state that they agree with all of the items concerning the content aspect of the textbooks. Accordingly, they state that they agree with the following items: when presenting new knowledge in the textbooks, the relationship to previous knowledge is provided $(\mathrm{X}=4.20)$; the examples provided to support the knowledge in the textbooks are sufficient $(\mathrm{X}=$ 4.18); the knowledge presented in the textbooks encourages students to do research, to take exams, to make observations and to think critically and the like $(X=4.14)$; the objectives, suggestions for further study, summary, and assessment questions facilitate comprehension of the unit $(X=4.08)$; the knowledge presented in the textbooks is useful for the aim of the preschool education field, its principles, methods, operations, and concepts $(X=3.96)$; the knowledge presented in the textbooks is valid and up-to-date $(\mathrm{X}=3.93)$; the knowledge presented in the textbooks is sequenced from the concrete to the abstract, from the simple to the complex, and from the known to the unknown $(\mathrm{X}=3.90)$; and the knowledge presented in the textbooks is sufficient to explain the subject $(\mathrm{X}=3.79)$. These findings indicate that teacher candidates find the content of the textbooks appropriate.

Preschool teacher candidates state that they agree with the following items concerning the language and narrative features of the textbooks: the lengths of words are convenient for reading skills $(X=4.16)$; paragraphs are written in a fluent, clear, and comprehensible way $(X=4.10)$; sentences are written in a short, clear, and grammatically correct way $(X=4.07)$; the punctuation marks are used correctly when presenting the subjects in the textbooks $(X=4.06)$; foreign words are avoided as much as possible $(\mathrm{X}=3.95)$; and the connections among the paragraphs in a text are well-established $(\mathrm{X}=3.91)$. Generally speaking, it can be concluded that teacher candidates find the content of the textbooks appropriate.

Preschool teacher candidates state that they also agree with the following items concerning the visual arrangement of the textbooks: the font of letters is compatible with the content and other components $(X=4.27)$; the space between lines is convenient for reading $(X=4.26)$; the arrangement of the titles facilitates comprehension $(X=4.23)$; page set-up facilitates reading and comprehension $(X=4.17)$; the font of letters in the textbooks is convenient for reading ( $X=$ 4.00); and pictures, photographs, figures, schemas, and graphics are explanatory and facilitate 
learning $(X=3.97)$. Generally speaking, it can be concluded that teacher candidates find the visual arrangement of the textbooks appropriate.

\section{Television programmes.}

The opinions of preschool teacher candidates on the television programmes are presented in

Table 5.

Table 5

The Opinions of Preschool Teacher Candidates on the Television Programmes

\begin{tabular}{|l|l|l|l|}
\hline Television programmes & $\mathbf{N}$ & $\mathbf{X}$ & $\mathbf{S S}$ \\
\hline The image of television broadcasts is of sufficient quality & 539 & 3.71 & 0.91 \\
\hline Television programmes support the units they are related to & 539 & 3.75 & 0.87 \\
\hline The number of the television programmes is sufficient & 539 & 3.18 & 1.05 \\
\hline $\begin{array}{l}\text { The broadcasting duration of television programmes is } \\
\text { sufficient }\end{array}$ & 539 & 3.03 & 1.07 \\
\hline $\begin{array}{l}\text { The broadcasting times of television programmes are } \\
\text { convenient }\end{array}$ & 539 & 3.01 & 1.11 \\
\hline $\begin{array}{l}\text { Television programmes are interesting, motivating, and } \\
\text { didactic }\end{array}$ & 539 & 3.48 & 1.03 \\
\hline Television programmes contribute to academic achievement & 539 & 3.43 & 0.80 \\
\hline $\begin{array}{l}\text { Television programmes facilitate comprehension of the } \\
\text { relevant unit }\end{array}$ & 539 & 3.77 & 0.90 \\
\hline Television programmes provide students with new knowledge & 539 & 3.81 & 0.86 \\
\hline $\begin{array}{l}\text { Television programmes aid in transforming what is learnt into } \\
\text { practice }\end{array}$ & 539 & 3.84 & 0.86 \\
\hline $\begin{array}{l}\text { Television programmes help students acquire attitudes and } \\
\text { skills in addition to knowledge }\end{array}$ & 539 & 3.81 & 0.88 \\
\hline $\begin{array}{l}\text { Television programmes allow for performing perception, } \\
\text { comprehension, evaluation and interpretation }\end{array}$ & 539 & 3.85 & 0.84 \\
\hline Television programmes activate students for new learning & 5396 & 3.78 & 0.88 \\
\hline General & $\mathbf{5 3 9}$ & $\mathbf{3 . 6 0}$ & $\mathbf{0 . 7 9}$ \\
\hline
\end{tabular}

Preschool teacher candidates state that they agree with the following items concerning the television programmes: television programmes allow for performing, perception, comprehension, evaluation, and interpretation $(X=3.85)$; television programmes aid in transforming what is learnt into practice $(\mathrm{X}=3.84)$; television programmes provide students with new knowledge $(\mathrm{X}=$ $3.81)$; television programmes help students acquire attitudes and skills in addition to knowledge $(\mathrm{X}=3.81)$; television programmes activate students for new learning $(\mathrm{X}=3.78)$; television programmes facilitate comprehension of the relevant unit $(\mathrm{X}=3.77)$; television programmes 
support the units they are related to $(X=3.75)$; the image of television broadcasts is of sufficient quality $(X=3.71)$; television programmes are interesting, motivating, and didactic $(X=3.48)$; television programmes contribute to academic achievement $(X=3.43)$. On the other hand, they state that they neither agree nor disagree with the following items: The number of the television programmes is sufficient $(\mathrm{X}=3.18$ ); the broadcasting duration of television programmes is sufficient $(X=3.03)$; the broadcasting times of television programmes are convenient $(X=3.01)$. Generally considered, it can be concluded that teacher candidates find the television programmes appropriate $(\mathrm{X}=3.60)$.

\section{Teaching practices.}

The opinions of preschool teacher candidates on the teaching practices are presented in Table 6 .

Table 6

The Opinions of Preschool Teacher Candidates on Teaching Practices

\begin{tabular}{|l|l|l|l|}
\hline Teaching Practices & $\mathbf{N}$ & $\overline{\mathbf{X}}$ & $\mathbf{S S}$ \\
\hline Teaching practices are professionally educative and beneficial & 1026 & 4.44 & 0.68 \\
\hline The number and duration of the teacher practices are sufficient & 1026 & 4.14 & 0.98 \\
\hline $\begin{array}{l}\text { The scheduled time and place of the teaching practices during } \\
\text { the year are convenient }\end{array}$ & 1026 & 4.11 & 0.98 \\
\hline $\begin{array}{l}\text { Teaching practices make it possible to transform theoretically } \\
\text { gained knowledge into practice }\end{array}$ & 1026 & 4.35 & 0.73 \\
\hline Organization (structure) of the teaching practices is good & 1026 & 4.21 & 1.49 \\
\hline $\begin{array}{l}\text { Teaching practice manuals sufficiently guide through planning, } \\
\text { observing, and implementing the activities }\end{array}$ & 1026 & 4.05 & 0.98 \\
\hline $\begin{array}{l}\text { The practice schools possess the convenient conditions in order } \\
\text { for the practices to be realized properly }\end{array}$ & 1026 & 4.35 & 1.80 \\
\hline General & $\mathbf{1 0 2 6}$ & $\mathbf{4 . 2 4}$ & $\mathbf{0 . 7 0}$ \\
\hline
\end{tabular}

Preschool teacher candidates state that they strongly agree with the following items concerning the teaching practices: teaching practices are professionally educative and beneficial $(X=4.44)$; teaching practices make it possible to transform theoretically gained knowledge into practice $(\mathrm{X}=$ 4.35); the practice schools possess convenient conditions in order for the practices to be realized properly $(X=4.35)$; and organization (structure) of the teaching practices is good $(X=4.21)$. On the other hand, they state that they disagree with the following items: the number and duration of the teacher practices are sufficient $(X=4.14)$; the scheduled time and place of the teaching practices during the year are convenient $(X=4.11)$; and teaching practice manuals sufficiently guide through planning, observing, and implementing the activities $(X=4.05)$. When the opinions of preschool teacher candidates concerning the teaching practices are broadly evaluated 
$(\mathrm{X}=4.24)$, it can be concluded that the teacher candidates find the teaching practices to be very positive.

\section{Examinations.}

The opinions of preschool teacher candidates on the examinations are presented in Table 7.

\section{Table 7}

The Opinions of Preschool Teacher Candidates on the Examinations

\begin{tabular}{|l|l|l|l|}
\hline Exams & $\mathbf{N}$ & $\overline{\mathbf{X}}$ & SS \\
\hline $\begin{array}{l}\text { The exam duration allocated for each course is sufficient to } \\
\text { answer the questions }\end{array}$ & 1026 & 4.18 & 0.91 \\
\hline The number of exam questions is sufficient & 1026 & 4.33 & 0.74 \\
\hline $\begin{array}{l}\text { Multiple-choice exam type is an appropriate measurement } \\
\text { technique }\end{array}$ & 1026 & 4.35 & 0.74 \\
\hline The questions measure what is learned & 1026 & 4.14 & 1.84 \\
\hline Exam dates are convenient & 1026 & 3.87 & 1.13 \\
\hline Exam questions are practical & 1026 & 3.73 & 1.06 \\
\hline Exam questions are comprehensive & 1026 & 3.82 & 1.06 \\
\hline $\begin{array}{l}\text { Exam questions are distributed reasonably among the subjects } \\
\text { learned }\end{array}$ & 1026 & 3.80 & 1.07 \\
\hline General & $\mathbf{1 0 2 6}$ & $\mathbf{4 . 0 3}$ & $\mathbf{0 . 7 3}$ \\
\hline
\end{tabular}

Preschool teacher candidates state that they strongly agree with the following items concerning the examinations: the multiple-choice exam type is an appropriate measurement technique $(\mathrm{X}=$ 4.35); the number of exam questions is sufficient $(X=4.33)$; the exam duration allocated for each course is sufficient to answer the questions $(X=4.18)$; and the questions measure what is learned $(X=4.14)$. Also, they state that they agree with the following items: exam dates are convenient $(X=3.87)$; exam questions are comprehensive $(X=3.82)$; exam questions are distributed reasonably among the subjects learned $(X=3.80)$; and exam questions are practical $(X=3.73)$. When the opinions of preschool teacher candidates concerning the examinations are evaluated in a general sense $(X=4.03)$, it can be concluded that the teacher candidates have positive views of the exams.

\section{Academic assistance services.}

The opinions of preschool teacher candidates on academic assistance services are presented in Table 8.

Table 8 
The Opinions of Preschool Teacher Candidates on Academic Assistance Services

\begin{tabular}{|l|l|l|l|}
\hline Academic Assistance & $\mathbf{N}$ & $\overline{\mathbf{X}}$ & $\mathbf{S S}$ \\
\hline $\begin{array}{l}\text { Communication with Open Education Faculty can be } \\
\text { established easily }\end{array}$ & 1026 & 3.72 & 1.13 \\
\hline There is immediate effort to solve the problems emerging & 1026 & 3.62 & 1.06 \\
\hline Any question is answered sufficiently & 1026 & 3.67 & 1.04 \\
\hline $\begin{array}{l}\text { The Web page of the Programme of Preschool Education } \\
\text { provides guidance }\end{array}$ & 1026 & 3.89 & 0.92 \\
\hline $\begin{array}{l}\text { Providing communication and interaction promote institutional } \\
\text { loyalty }\end{array}$ & 1026 & 4.00 & 0.90 \\
\hline General & 1026 & 3.78 & 0.86 \\
\hline
\end{tabular}

Preschool teacher candidates state that they agree with all the following items concerning the academic assistance services: providing communication and interaction promote institutional loyalty $(X=4.00)$; the Web page of the Programme of Preschool Education provides guidance ( $X$ = 3.89); communication with Open Education Faculty can be established easily ( $\mathrm{X}=3.72)$; any question is answered sufficiently $(\mathrm{X}=3.67)$ and there is immediate effort to solve emerging problems $(X=3.62)$. When the opinions of preschool teacher candidates concerning the academic assistance services are examined carefully $(X=4.03)$, it can be concluded that the teacher candidates view the academic assistance services very positively.

\section{Conclusion and Discussion}

Anadolu University's Preschool Education Programme, which trains preschool teacher candidates through distance and face-to-face education, is a unique undergraduate programme. In this respect, the programme is implemented with an aim different from that of other distance teacher training practices that are carried out in order to increase the qualifications of teachers working within the system or to provide career development. This model completely matches what Miller (2000) states about the distance teacher training models in Jamaica: "distance education is a feasible, practical, and appropriate modality for delivering formal teacher education and supporting changes in teaching strategies related to reforms in education system" (p. 147). The books and television programmes produced within the scope of the programme contribute significantly to teacher training. Moreover, the television programmes broadcast around the country support not only the teacher candidates studying the major but also the adults who study child development and education issues.

Aimed at determining the opinions of the preschool teacher candidates who are trained via the distance education approach, this research study indicates that the programme was found to be positive by students. The findings of this research study match those of many others, which state that teacher training through distance education can be implemented efficiently and effectively and 
that it yields positive outcomes. Teacher candidates believe that the program equips them "satisfactorily" with the necessary knowledge, skills, and attitudes. A small number of the candidates think the program provides them with the necessary knowledge, skills, and attitudes "in the best way." Also, this fundamental finding of the research is in harmony with Yaşar and Gültekin's (2006) research, which found that the candidates in the Open Education Faculty think the program enables them to gain the knowledge, skills, and attitudes relevant to the teaching Page | 16 profession at a "moderate level," and they are capable of using these knowledge, skills, and attitudes at a "moderate level." The study revealed that the attitudes of teacher candidates towards the teaching profession are quite positive, and their perception levels of their teaching competency are very good. Moreover, the teacher candidates consider the program they enrolled in beneficial in terms of gaining teaching competencies. Similarly, in another study conducted by Gültekin (2006b), teacher candidates in the same program believe that their attitudes regarding the teaching profession are positive and their teaching competencies are good.

Also, the research completely agrees with Carr, Fung, and Chan's finding (2002) that most students meet the requirements of the programme, they feel pleased to participate in the programme, and the programme has a positive influence on them; Phillion, Johnson, and Lehman's finding (2004) that the experiences in the distance teacher training programme are beneficial in terms of teaching, reflect real life, increase the technological competency of teachers, prepare preschool-service teachers better in terms of teaching, and encourage the use of technology for teaching; Anderson and Simpson's finding (2005) that the distance teacher training programme has some positive impacts on the teaching practices performed by teachers; and Pham's finding (2002) that the programme is considered to be efficient by students as its fundamental objectives are clear and comprehensible. In addition, this study's results are supported by Cooper and Keefe's finding (2001), indicating that trainee teachers are content with the programme in general and Kim's finding (1999) showing that the programme is found to be successful by teachers and also Kim's finding (2000) showing that the Web-based in-service training program is deemed satisfactory by students. Furthermore, this study's findings are supported by Chivore's finding (1992), which points out that the distance education programme is effective in terms of the introduction to the lessons, lesson development, teacher-student interaction, techniques for asking questions, classroom control, and classroom management involving student participation.

According to this study, nearly two of every five preschool teacher candidates participating in the survey do not study for their lessons systematically, but the remainder study for their lessons every day. Almost half the preschool teacher candidates involved in the survey do not watch the television programmes at all, but most of the remaining students watch them more or less. This finding of the research agrees with another research study performed by Hakan, Özgür, Kara, Kürüm, and Özkanal (2004), which found that students believe television programs are an important part of the system; however, this finding is not consistent with another finding revealing that teacher candidates cannot use television programs efficiently. There may be many reasons for these low levels of television watching by students. In addition to the personal characteristics of the teacher candidates, competing television programs' broadcast on state channels and unfavourable broadcast times may cause the problem. Similarly, in another study 
conducted by Bir (1996), it was found that students' television watching levels are low and the main reason (49.6\%) for that is the inappropriate broadcast time of the programs.

The tendency of teacher candidates regarding the television programmes agrees with the finding of Kim (1999) showing that teachers do not watch the cable television broadcasts and the findings of Candemir (2002), Özer (1989), Uşun (2003), Yüksel (1987) and Yüksel (1990), pointing out that teachers watch the programmes rarely.

Concerning the textbooks, the teacher candidates find the physical features, content, language, narrative qualities, and visual design of the textbooks positive. This finding of the study agrees with the findings of Hakan, Özgür, Kara, Kürüm, and Özkanal (2004), which discovered that Open Education Faculty students believe that optimization of page layouts and print makes their reading easy, and the goals, warnings, abstracts, and assessment questions make it easy to learn. The findings of the survey also agree with Fung's finding (2005), indicating that course materials are very efficient in order for teachers to achieve their aims. Also, this finding of the survey completely agrees with Sakar's finding (2002) that students are satisfied with the print quality of the textbooks and Hakan's finding (1991) that the textbooks designed in accordance with distance teaching techniques facilitate learning and are comprehended easily.

Although the opinions of the preschool teacher candidates on the television programmes are positive in general, it was determined that the level of watching the programmes is not high. Considering that the tendency of teacher candidates to watch the television programmes is not high, it is evident that the television programmes need to be improved.

When the data concerning the opinions of teacher candidates on the teaching practices are examined, it is revealed that teacher candidates find the teaching practice activities quite positive and supportive. Teaching practices have a significant place in this program because they include the activities whereby students transform the knowledge and skills they have gained through theoretical courses into practice. The fact that the program is in use with a great number of students across the country shows that the applications are conducted in a planned and appropriate way. This finding of the survey agrees with Lea's finding (2000) that the practice experiences of students' enrich teaching; Pham's finding (2002) that the programme improved students' skills in planning and teaching; and Stobart and Chau's finding (2002), which is stated as the following: "There was again a general feeling amongst the students that the SOLE environment was such a good learning experience that it made the students more productive, allowing them to learn at an increased speed." In addition, the findings by Fung (2005), Anderson and Simpson (2005), Russell (1996), Stubbs and Burnham (1990), Schlosser and Anderson (1994), Özer (1989), and Burnham and Seamons (1987), which point out that distance teacher training programmes provide students with effective learning experiences, support this finding of the survey.

Preschool teacher candidates generally have positive opinions regarding examinations. Teacher candidates have favourable views of the duration of the exams, number of questions in the exams, the exam dates, content of the exams, and the quality of the questions. The exam-related findings 
of the study agree with Hakan, Özgür, Kara, Kürüm, and Özkanal's (2004) study, which revealed that open education students believe the number of questions on the exams is sufficient and multiple-choice is the most appropriate question type. In particular, the positive finding of the survey that "Multiple-choice exam type is an appropriate measurement technique," completely agrees with Fung's finding (2005) that the vast majority of teacher candidates use test activities when reading the unit; Hakan's finding (1991) that the multiple-choice question type is the best way to measure achievement and knowledge; and Şakar's finding (2002) that the way the exam questions are asked, the time given for answering, and the comprehensibility of the questions are considered to be satisfactory by students. However, this finding of the survey does not agree with Kim (1999) and also Kim (2000), who stated that the evaluation was done through multiplechoice type questions, which might be inappropriate in terms of the nature of open education.

When the data concerning the opinions of teacher candidates on the academic assistance services are analyzed, it is found that teacher candidates consider the academic support services to be positive. The teacher candidates could easily get in touch with the faculty and find solutions for their problems. This finding of the survey is similar to Jackson's (2006) and Carr, Fung, and Chan's (2002) finding that the vast majority of students studying through distance education find the technical support, seminar, and academic assistance satisfactory and to the findings by Greer, Hudson, and Paugh (1998), Buckley (1993), Gruenhagen, McCracken, and True (1999), Kim (2000), and Perraton, Creed, and Robinson (2002) that distance education programmes are successful in academic assistance.

In conclusion, the teacher candidates in the Programme of Preschool Education of Anadolu University have a good level of studying but not a good level of watching the television programmes. As well, it can be concluded that the opinions of teacher candidates about the aims of the programme, the courses offered in the programme, textbooks, television programmes, teaching practices, exams and academic assistance facilities are positive.

The following can be recommended in light of the research results:

1. The reasons why preschool teacher candidates trained through the distance education approach do not watch the television programmes should be researched.

2. The Programme of Preschool Education should be evaluated continuously and then be improved based on these evaluation results. In particular, the television programmes should be improved and academic assistance services should be rendered more efficient.

3. Web-based interactive teaching opportunities should be utilized more in the Programme of Preschool Education.

4. The Open Education Faculty Programme of Preschool Education should also be evaluated based on the opinions of other officials, namely provincial coordinators from the Ministry of Education, coordinators at practice schools, practice teachers, and students. 
5. The Programme of Preschool Education should also be evaluated by means of qualitative studies

Page $\mid 19$ 


\section{References}

Anadolu University (2004). Programme of Preschool Education. Retrieved June 10, 2004, from http://www.aof.anadolu.edu.tr

Anderson, B. \& Simpsson, M. (2005). From distance teacher education to beginning teaching: What impacts on practices. Retrieved June 16, 2004, from http://www.unisa.edu.au/odlaaconference/PDFs/70\%20ODLAA\%202005\%20$\% 20$ Anderson\%20\&\%20Simpson.pdf

Bir, A. A. (1996). 1995-1996 academic year student survey. Eskişehir: Anadolu University Open Education Faculty Publications.

Brophy, M. \& Dudley, B. (1983). Training teachers in the world. Teaching at a Distance, 23, 4045.

Buckley, H. (1993). Course completion survey on the delivery process and the course content of the OCOD-CTTP distance education project: Learner survey. St Lucia: Organization for Cooperation in Overseas Development.

Burnham, B. R. \& Seamons, R. A. (1987). Exploring the landscape of electronic distance education: Lifelong learning. An Omnibus of Practice and Research, 11(2), 8-11.

Candemir, A. (2002, May). The television broadcasting facilities and conditions of open education faculty. Symposium on Open and Distance Education. Turkey.

Carr, R., Fung, Y. \& Chan, S. K. (2002). Distance education for teacher education: Hong Kong experience. Journal of In-Service Education, 28(1), 163-176.

Chivore, B.R.S. (1992). Pre-service teacher education at a distance: The case of Zimbabwe. In P. Murphy and A. Zhiri (Eds), Distance education in Anglophone Africa. EDI Development Policy Case Series, No. 9. Washington, DC: The World Bank.

Cooper, H. \& Charlotte, H. K (2001). Preparation of teachers of visually impaired students via distance education of teachers. Journal of Visual Impairment \& Blindness, 95(9), 563566 .

Demiray, U., Mc Isaac, M. S. \& Yangın, G. (1993). Distance education for primary and secondary teacher training in Turkey. An International Survey of Distance Education Teacher Training from Smoke Signal to Satellite. Orlando: University of Central Florida. (ERIC Document Reproduction Service No. ED377815)

Edwards, F. (2005). The neglected heart of educational development: primary teacher education strategy in Malawi. Journal Education for Teaching, 31(1), 25-36. 
Evans, T. (1994). Understanding learners in open and distance education. London: Kogan Page.

Evans, T. \& Nation, D. (1993). Educating teachers at a distance in Australia: Some trends. In H. Perraton (Ed.), Distance education for teacher training. London: Routledge.

Fung, Y. H. (2005). Teachers' views on and use of printed materials in a distance learning teacher education course. Open Learning, 20(2), 175-183.

Greer, L. B., Hudson, L. \& Paugh, R. (1998, October). Student services and success for adult, online learners. Paper presented at the annual conference of the International Society for the Exploration of Teaching Alternatives, Cocoa Beach, FL.

Gultekin, M. (2004). Teaching practices in teacher training programmes. In M. Gultekin (Ed.), Practical manual in preschool education for teacher candidates and teachers (pp. 110). Eskişehir: Anadolu University Open Education Faculty Press.

Gültekin, M. (2006a). Using of distance education approach in teacher training: Anadolu Universty Open Education model. The Turkish Online Journal of Educational Technology - TOJET, 5(1).

Gültekin, M. (2006b). The attitudes of preschool teacher candidates studying through distance education approach towards teaching profession and their perception levels of teaching competency. Turkish Online Journal of Distance Education-TOJDE, 7(3).

Gruenhagen, K, McCracken T. \& True, J. (1999) Using distance education technologies for the supervision of student teachers in remote rural school. Rural Special Education Quarterly, 18.

Hakan, A. (1991). Evaluation of two-year undergraduate education programme. Eskisehir: Open Education Faculty, Anadolu University Press.

Hakan, A., Özgür, A: Z., Kara, E. Kürüm, D. \& Özkanal, B. (2004). The evaluation of graduate programs of open education system. Eskişehir: Anadolu University Open Education Faculty Publications Anadolu Üniversitesi.

Jackson, B. G. (2006). Distance technology teaching: A view from the trenches. Retrieved Junuary 20, 2006, from http://www.techknowlogia.org/TKL_active_pages2/CurrentArticles/main.asp?IssueNu mber $=18 \&$ FileType $=$ HTML $\&$ ArticleID $=447$

Kim, J.W. (1999). Distance education for in-service primary teacher training in Korea: KNOU case. (Korea National Open University). Paper presented at the seminar hosted by the 
Institute of Pedagogics and Educational Research, Fernuniversitat Esamthochschule in Hagen, Germany.

Kim, J. W. (2000). On-line secondary teacher in-service training in Korea: A KNOU case. Retrieved June 25, 2006, from http://www.ulaval.ca/aced2000cade/francais/Actes/ JaeWoong-Kim.html

Lea, M. (2000). The use of open and distance learning in pre-school teacher education report. (ERIC Document Reproduction Service No. ED448875)

Martinez, A. (2002). Distance learning and teacher education. Karen's Linguistics Issues. Retrieved June 25, 2006, from http://www3.telus.net/linguisticsissues/longdistance.html

Miller, E. (2000). Models in distance teaching in teacher education in Jamaica. Proceedings of Distance Education in Small States Conference. The University of the West Indies Distance Education Centre (UWIDEC), Ocho Rios, Jamaica. http://www.col.org/resources/publications/monographs/Pages/2000SmallStates.aspx

Moon, B. (1997). Open learning and new technologies in teacher education: New paradigms for development. European Journal of Teacher Education, 20(1), 193-217.

Murphy, K. (1993). Pedagogy through distance education. An international survey of distance education teacher training. From smoke signal to satellite. Orlando: University of Central Florida. (ERIC Document Reproduction Service No. ED377815)

Nielsen, H. \& Tatto, M. T. (1991). The cost effectiveness of distance education for teacher training. In BRIDGES Research Report Series, No. 9. Cambridge, MA: Harvard University.

Özer, B. (1993). Acquisition of teacher behaviour through distance education. Eskisehir: Education Faculty, Anadolu University Press.

Özer, B. (1989). The effectiveness of two-year education programme carried out through distance education approach in terms of gaining the knowledge of teaching profession. Unpublished doctoral dissertation, The Institute of Social Sciences, Anadolu University, Eskisehir.

Pham, M. (2002) Distance education in teacher education. Retrieved May 10, 2005 from http://www.uwm.edu/Dept/Grad_Sch/McNair/2002/pham.html

Phillion, J. A., Johnson, T. \& Lehman, J. D. (2004). Using distance education technologies to enhance through linkages with K-12 schools. Journal of Computing in Teacher Education, 20(2). 63-70. 
Perraton, H., Creed, C. \& Robinson, B. (2002). Teacher education guidelines: Using open and distance learning. Paris: UNESCO. Higher Education Division, Teacher Education Section.

http://unesdoc.unesco.org/images/0012/001253/125396e.pdf

Perraton, H., Creed, C., \& Robinson, B. (2001). Teacher education through distance learning: Technology-curriculum-cost-evaluation. Paris: UNESCO. Higher Education Division, Teacher Education Section.

Prescott, W. \& Robinson, B. (1993). Teacher education at the Open University. In H. Rabinson \& C. Latchem (Eds.), Teacher education through open and distance education. London: Routledge.

Robinson, B. \& Latchem, C. (2003). Teacher education: challenge and change. In B. Robinson \& C. Latchem (Eds.), Teacher education through open and distance education. London: Routledge.

Russell, T. L. (1996). The "no significant difference phenomenon" as reported in 214 research reports, summaries, papers. Raleigh, NC: North Carolina State University Press.

Schlosser, C. A. \& Anderson, M. L. (1994). Distance education: Review of the literature. Ames, IA: Research Institute for Studies in Education, Iowa State University.

Sherestha, G. (1997). A review of case studies related to distance education in developing countries. Retrieved June 10, 2004, from http://www.undp.org/info21/public/review/pbrev.html

Stobart, S. \& Chau, P. (2002). Postgraduate student perspectives of using an on-line learning environment. Turkish Online Journal of Distance Education-TOJDE 3(3).

Stubbs, S. T. \& Burnham, B. R. (1990). An instrument for evaluating the potential effectiveness of electronic distance education systems. The American Journal of Distance Education, 4(3), 25-37.

Şakar, N. (2002). A research into the opinions of sudents undergraduate programme of English teaching at Anadolu University Open Education Faculty and the conclusions. Symposium on Open and Distance Education, Eskişehir, Turkey.

Uşun, S. (2003). The applications and problems on the distance teacher training in Turkey. Turkish Online Journal of Distance Education-TOJDE. 4(4).

Yasar, Ş., Gültekin, M., \& Duban N. (2006). The structure and the applications of practical activities in the pre-school teacher training program in the open education faculty at 
Anadolu University in Turkey. Paper presented at the IV International Conference on Multimedia and Information and Communication Technologies in Education, Seville, Spain.

Yasar, S. \& Gültekin, M. (2006). The perceptions of teacher candidates in the preschool teacher training program of open education faculty on teaching profession. International and Page | 24 Distance Learning (IODL) Symposium in Lifelong Open and Flexible Learning in the Globalized World, Eskişehir, Türkiye.

Yates, C. (2000). Teacher education at a distance: lessons and experiences from Sub-Saharan Africa. Cambridge: International Extension College.

Yüksel, A. H. (1987). Some notes on TV course production which were broadcast by Anadolu University Open Education Faculty for teacher training. Journal of National Education, $74,48-61$.

Yüksel, C. (1990). An evaluation of radio programs which were produced by open education faculty from points of teachers view in teacher training. Unpublished master's thesis, Anadolu University, Institute of Social Sciences, Eskisehir.

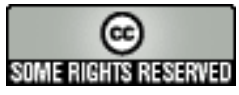

